\section{Bell Pepper (Capsicum annum L.) under Colored Shade Nets: Fruit Yield, Postharvest Transpiration, Color, and Chemical Composition}

\author{
Juan Carlos Díaz-Pérez \\ Department of Horticulture, University of Georgia, 2360 Rainwater Road, \\ Tifton, GA 31793
}

Kelly St. John

Trellis Growing Systems LLC, 2427 S. Hadley Road, Fort Wayne, IN 46804

Mohammad Yamin Kabir and J. Alberto Alvarado-Chávez

Department of Horticulture, University of Georgia, 2360 Rainwater Road, Tifton, GA 31793

Ania M. Cutiño-Jiménez

Departamento de Biología y Geografia, Facultad de Ciencias Naturales y Exactas, Universidad de Oriente, Santiago de Cuba, Cuba

Jesús Bautista and Gunawati Gunawan

Department of Horticulture, University of Georgia, 2360 Rainwater Road, Tifton, GA 31793

Savithri U. Nambeesan

Department of Horticulture, University of Georgia, Athens, GA 30602

Additional index words. antioxidant, climate change, fruit sunscald, heat stress, plasticulture, shade house

\begin{abstract}
Colored shade nets may affect plant growth and fruit yield of horticultural crops. The understanding of how colored shade nets influence plants, however, is far from complete. The objective of this study was to determine the effects of colored shade nets on bell pepper fruit yield, postharvest transpiration, color, chemical composition, and antioxidant capacity. The experiment was conducted in Tifton, GA, during the spring of 2015 and 2016. The experimental design was a randomized complete block with four replications and five colored shade net treatments (black, red, silver, and white nets, and an unshaded control). The nets were placed on the top of wooden rectangular structures $(15 \mathrm{~m}$ wide $\times 6 \mathrm{~m}$ long $\times 5 \mathrm{~m}$ high), leaving the sides of the structures uncovered. Results showed that in both 2015 and 2016, marketable and total fruit number, yield, and individual fruit weight were reduced under the unshaded treatment. There were inconsistent differences in marketable and total fruit number, yield, and individual fruit weight among colored shade nets. Postharvest fruit transpiration and skin permeance were also reduced in unshaded conditions, and no differences were found among colored shade nets. Fruit color $L^{*}$ and $b^{*}$ values were highest, and a* value was lowest in unshaded conditions. Fruit soluble solids, total phenols, flavonoids, and antioxidant capacity [Cupric Reducing Antioxidant Capacity (CUPRAC) and Trolox Equivalent Antioxidant Capacity (TEAC)] responded differently among colored shade nets in the 2 years. Total phenols, flavonoids, and TEAC, however, were among the highest in unshaded conditions. In conclusion, results of the present study support previous findings that shade nets increase fruit yield and quality in bell pepper compared with fruit produced in unshaded conditions. Nevertheless, there were no consistent differences in fruit total and marketable yield and postharvest fruit transpiration and chemical composition of fruit produced under colored shade nets.
\end{abstract}

Chilies or peppers (Capsicum annuum L.) originated in Mexico, Central America, and northern South America (Wien, 1997). Bell pepper or sweet pepper is a nonpungent group of the species $C$. annuum. Bell pepper grows well in warm conditions, but fruit set, yield, and quality may be severely affected under high temperatures and solar radiation. The optimal mean air temperature for bell such as sunscald (Díaz-Pérez, 2014; Ilic et al., 2011; Kong et al., 2013; Rylski, 1986). Although black nets are most commonly used, there has been increasing interest on utilization of colored nets.

Colored shade nets have been found to improve plant growth and fruit yield in horticultural crops (Stamps, 2009). In bell pepper, colored shade nets have shown to increase fruit yield and quality, such as reduction in incidences of physiological disorders (Ilic et al., 2017; Ombódi et al., 2015; Shahak, 2008). Colored shade nets can influence plant morphology and physiology by affecting plant photoreceptors, such as phytochromes (Cerny et al., 2003; Stamps, 2009). Effects of colored shade nets on crops are not always consistent and may vary depending on environmental conditions and crops (Stamps, 2009). The effects of colored shade nets on microclimate and plant growth and physiological responses are reported in a companion study (Díaz-Pérez and St. John, 2019). There is limited information on the effects of colored shade nets on fruit chemical composition and antioxidant activity (Ilic et al., 2017). The objectives of the present study were to determine the effects of colored shade nets on bell pepper fruit yield, postharvest transpiration, color, chemical composition, and antioxidant activity.

\section{Materials and Methods}

The study was conducted at the Horticulture Farm, University of Georgia (UGA), Tifton, GA, during the spring seasons of 2015 and 2016. The soil was a Tifton Sandy Loam (a fine loamy-siliceous, thermic Plinthic Kandiudults) with a $\mathrm{pH}$ of 6.5 . Before laying mulch with a mulch-laying machine, the soil was fertilized with nitrogen $(\mathrm{N})$, phosphorus $(\mathrm{P})$, and potassium $(\mathrm{K})$ at $50.0,22.0$, and $46.1 \mathrm{~kg} \cdot \mathrm{ha}^{-1}$, respectively, using 10-10-10 granular fertilizer. At the same time plastic film mulch [black, low density polyethylene with a slick surface texture, $1.52 \mathrm{~m}$ wide and $25 \mu \mathrm{m}$ thick (Intergro, Clearwater, FL)] was laid, drip irrigation tape $[30 \mathrm{~cm}$ emitter spacing and a 12.6 $\mathrm{mL} \cdot \mathrm{min}^{-1}$ emitter flow at 0.55 bar of pressure (Toro, Aqua traxx, Abilene, TX)] was placed 5 $\mathrm{cm}$ deep in the center of the bed.

Bell pepper ('PS 09979325') transplants were produced in a greenhouse using peatbased medium (Pro-Mix, Quakertown, PA) and polystyrene 200 -cell $(2.5 \times 2.5$-cm cell $)$ trays Six-week-old transplants were planted on 12 Apr. 2015 and 20 Apr. 2016 on two rows per bed, with a $30-\mathrm{cm}$ separation between plants and $36-\mathrm{cm}$ separation between rows. Plants were established on individual raised beds (formed on 1.8-m centers; 0.76-m wide). The length of the field experimental plot was $6 \mathrm{~m}$. Approximately $240 \mathrm{~mL}$ of starter fertilizer solution (555 ppm N; 821 ppm P; 0 ppm K) was applied directly to the base of each transplant. Starting 3 weeks after transplanting, plants were fertilized weekly through the drip system. Total major nutrients applied were 200 $\mathrm{kg} \cdot \mathrm{ha}^{-1} \mathrm{~N}, 22 \mathrm{~kg} \cdot \mathrm{ha}^{-1} \mathrm{P}$, and $194 \mathrm{~kg} \cdot \mathrm{ha}^{-1} \mathrm{~K}$. The 
crop was grown following the recommendations of the UGA Extension Service.

Experimental design was a randomized complete block with four replications and five colored shade treatments (four colored nets and an unshaded control). Colored nets were black ( $47 \%$ shade), red ( $42 \%$ shade), silver $(40 \%$ shade), and white (41\% shade) (Fig. 1). Shade factors are as reported by the manufacturer (Green-tek, Janesville, WI) and are within the optimal shade level ( $30 \%$ to $46 \%$ shade) for bell pepper (Diaz-Pérez, 2014). Nets were placed on the top of wooden rectangular structures $(15 \mathrm{~m}$ wide $\times 6 \mathrm{~m}$ long $\times 5 \mathrm{~m}$ high $)$, leaving the sides of the structures uncovered.

Plants were irrigated with an amount of water equivalent to $100 \%$ of the crop evapotranspiration (ETc), which was calculated by multiplying the reference evapotranspiration (ETo) by the crop factor (dependent on the crop stage of development). Water was applied when cumulative ETc was $12 \mathrm{~mm}$, which corresponded to approximately every 2 to $3 \mathrm{~d}$ in mature plants (mean ETo was $5 \mathrm{~mm} \cdot \mathrm{d}^{-1}$ ).

Microenviroment. Air temperature and relative humidity were measured periodically during the season (both in 2015 and 2016) with dataloggers (HOBO, MX2301A; Instrumart, Burlington, VT). Data for white treatment were not collected due to datalogger malfunction. Root zone temperature ( $8 \mathrm{~cm}$ deep) was measured manually at midday with a digital thermometer. The ETo and rainfall data were obtained from a nearby UGA weather station (less than $300 \mathrm{~m}$ ). Leaf temperature was measured with the copper constantan thermocouple of an infrared (IR) gas analyzer [LI-COR 6400 IRGA with an integrated 6400-40 leaf chamber fluorometer (LI-COR, Inc., Lincoln, NE)]. Measurements were conducted in developed plants on clear days [photosynthetically active radiation $(P A R)>1900 \mu \mathrm{mol} \cdot \mathrm{m}^{-2} \cdot \mathrm{s}^{-1}$ in unshaded conditions] at 1200-1500 HR Eastern Standard Time using two developed and fully exposed leaves.

Harvest. Bell pepper fruit was harvested and graded according to US Department of Agriculture (USDA) standards as marketable and nonmarketable (USDA, 2005). Number for publication 15 Nov. 2019.

Published online 10 January 2020.

We thank Nélida Bautista for her invaluable technical support, and Jason Brock of the Plant Disease Clinic, University of Georgia, for identification of plant diseases. We appreciate the thorough review of the manuscript by Lenny Wells and Darío Chávez and the anonymous reviewers. Financial support was provided by the Georgia Agricultural Experiment Stations. This material is based on work that is supported by the National Institute of Food and Agriculture, U.S. Department of Agriculture, under award number 2014-33610-22604. Financial support provided by the Georgia Agricultural Experiment Stations is appreciated.

Mention of trade names in this publication does not imply endorsement by the University of Georgia of products named, nor criticism of similar ones not mentioned.

J.C.D.-P. is the corresponding author. E-mail: jcdiaz@ uga.edu.

This is an open access article distributed under the CC BY-NC-ND license (https://creativecommons. org/licenses/by-nc-nd/4.0/).
Received for publication 7 Aug. 2019. Accepted and weight of marketable, nonmarketable, and total (marketable + nonmarketable) fruit were determined and expressed on a per hectare basis. Average fruit weight was derived mathematically from the marketable fruit weight and the number of marketable fruit. There were seven harvests in 2015 (15 June-31 July) and four in 2016 (21 June-6 July).

Fruit transpiration. Fruit transpiration or water loss rate was measured by placing fruit on trays (15 fruit per treatment) and kept in a controlled-temperature room $\left(20{ }^{\circ} \mathrm{C}\right.$, vapor pressure difference of $1.50 \mathrm{kPa}$ and air velocity of $<0.2 \mathrm{~m} \cdot \mathrm{s}^{-1}$ ). Fruit water loss was measured gravimetrically by weighing individual fruit daily for $7 \mathrm{~d}$. The rate of water loss $(W L R)$ was determined as a daily percent weight loss of the fruit with respect to the fruit weight the day before each measurement. The fruit $W L R$, surface area (SA), and transpiration ratio or permeance to water vapor $\left(P_{\mathrm{H} 2 \mathrm{O}}\right)$ were calculated as follows (Díaz-Pérez et al., 2007):

$W L R\left(\%\right.$ loss day $\left.{ }^{-1}\right)=\left(\Delta F W / F W_{o}\right)(100 / t)$

$S A=-0.0026 x F W_{o}^{2}+1.797 x F W_{o}+23.06$

$P_{H 2 O}\left(\mu \mathrm{molm}^{-2} \mathrm{~s}^{-1} \mathrm{kPa}^{-1}\right)=\left[\right.$ WLR $x F W_{o} x$ $\left.\left(6.43 \times 10^{-3}\right)\right] /(S A x V P D)$
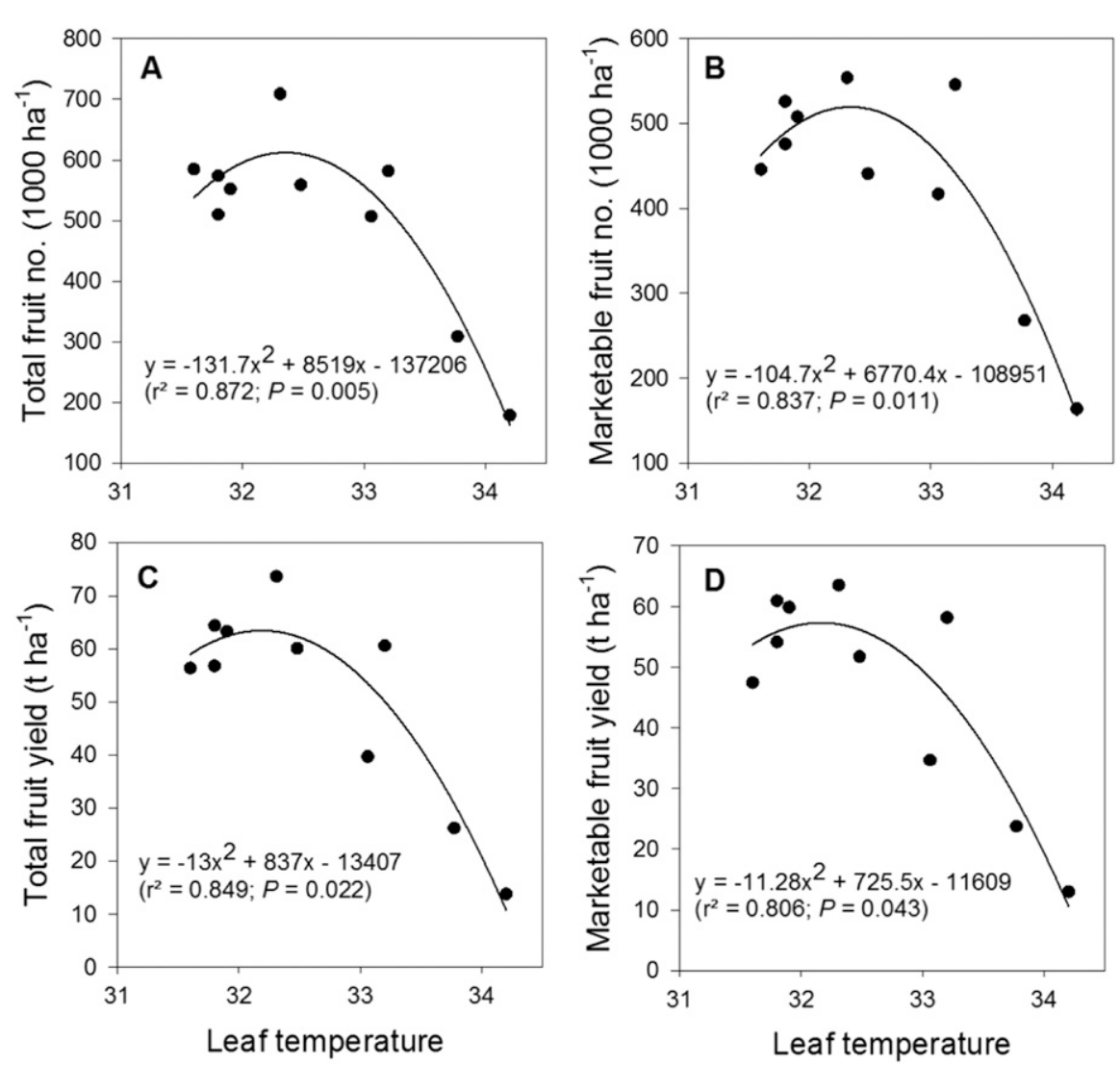

Fig. 1. Relationship between total fruit number (A), marketable fruit number $(\mathbf{B})$, total fruit yield (C), and marketable fruit yield (D) with midday leaf temperature $\left({ }^{\circ} \mathrm{C}\right)$ in bell pepper under colored shade nets. Fruit harvested at the mature green stage, Tifton, GA.

where $\Delta F W$ is the change in fruit $F W(\mathrm{~g})$ and $t$ is the time period (day) between two consecutive fruit $F W$ determinations; $F W_{o}$ is fruit $F W$ at the beginning of the weighing period; $6.43 \times 10^{-3} \mu \mathrm{mol} \cdot \mathrm{m}^{-2} \cdot \mathrm{s}^{-1}$ is a conversion factor; $S A$ is whole-fruit surface area $\left(\mathrm{m}^{2}\right)$; and $V P D$ is water vapor pressure deficit $(\mathrm{kPa})$ under storage. Mean values of $W L R$, $S A$, and $P_{H 2 O}$ were calculated for individual fruit from measurements made over a 7-day period. The mean fruit weights $\left(F W_{o}\right)$ used were $125.2 \mathrm{~g}$ (unshaded), $128.5 \mathrm{~g}$ (black), $150.1 \mathrm{~g}$ (red), 161.3 (silver), and 165.4 (white).

Fruit color. Postharvest attributes (except transpiration) were measured in 20 mature green fruit per treatment (five fruit per plot). Fruit skin color was measured (four readings per fruit) with a CR-400 (8 mm aperture, D65 illuminant) handheld colorimeter (Konica Minolta, Ramsey, NJ). Color was measured as $L^{*}, a^{*}, b^{*}$. Lightness ( $L^{*}$ value) goes from 0 (white) to 100 (black); a* value from -a (green) to $+\mathrm{a}$ (red); $\mathrm{b}^{*}$ value from $-\mathrm{b}$ (blue) to $+\mathrm{b}$ (yellow) (McGuire, 1992).

Fruit chemical attributes. A fruit juice sample was obtained from individual fruit by manually squeezing a portion of the fruit pericarp and filtering the juice through two layers of cheesecloth. Eight fruit were evaluated per shade net treatment. Soluble solids content (SSC) was measured using a Brixstix digital handheld refractometer (3810
HortScience Vol. 55(2) February 2020 
PAL-1; Atago, Livermore, CA), which was calibrated with distilled water. Total phenols were determined as a measure of total antioxidant capacity following the FollinCiocalteau method (Singleton et al., 1999) and data were expressed as gallic acid equivalents. Total flavonoid concentrations were determined using a methanolic extract and expressed as quercetin equivalents (Rawat et al., 2014). Antioxidant capacity was determined by the TEAC and the CUPRAC methods (Barros et al., 2007; CastroConcha et al., 2014).

Statistical analysis. Data were analyzed using the General Linear Model and Regression Procedures from SAS (SAS version 9.4; SAS Institute, Inc., Cary, NC). Data means were separated by Fisher's protected least significant difference test at $95 \%$ confidence. Percentages were transformed to arcsin values before analysis. For clarity, nontransformed percentage means were used for presentation in tables and figures. Data are presented by year because there were significant treatment by year interactions.

\section{Results}

Microclimatological factors. Seasonal air temperature and relative humidity and midday leaf and root zone temperature and $P A R$ for both 2015 and 2016 seasons are shown in Tables 1 and 2.

Fruit yield. In 2015, marketable fruit number and yield, total fruit yield, and weight of individual fruit were reduced in unshaded conditions (Table 3 ). There were no differences in fruit yield or individual fruit weight among colored shade nets. In 2016, marketable yield was highest in silver net and lowest in unshaded conditions and under white net (Table 4). Individual fruit weight was lowest in unshaded conditions in both years. Although fruit number and yield responses to colored shade nets varied by year, overall reduction in fruit number and yield in unshaded conditions was consistent in both years. Midday leaf temperature under shade net treatments was related to fruit yield of bell pepper plants. Midday leaf temperature between 31.5 and $32.5^{\circ} \mathrm{C}$ had little effect on fruit yield. Marketable and total fruit number and yield decreased with increasing midday leaf temperature above $32.5^{\circ} \mathrm{C}$ (Fig. 1).

Postharvest fruit transpiration. Fruit water loss rate and skin permeance were the lowest in fruit from unshaded conditions (Fig. 2). There were no differences in fruit WLR and skin permeance between colored shade nets.

Fruit skin color. Fruit skin color values were affected by shade treatments (Fig. 3).
Fruit $L^{*}$ value was highest in unshaded treatment and lowest under black and silver nets. Fruit $a^{*}$ value was the lowest (most negative) in unshaded treatment and the highest (least negative) under black and red nets. Fruit $b^{*}$ value was the highest in unshaded conditions and the lowest under black net.

Fruit chemical attributes. In 2015, SSC was highest under red net and lowest under black net (Table 5). In general, total phenols, flavonoids, CUPRAC, and TEAC values were among the highest in unshaded treatment and under white net and among the lowest under black net. In 2016, SSC was unaffected by shade treatments, although, as in 2015 , SSC showed reduced values under black net (Table 6). Similar to 2015, in 2016, total phenols, flavonoids, and TEAC values were the highest in unshaded treatment. CUPRAC was lowest in 2015 and highest in 2016 under black net.

\section{Discussion}

Shade nets affect the quality and quantity of solar radiation received by the crop as well as the air and soil temperature under the net, resulting in improvements of plant growth and fruit yield and quality (Arthurs et al., 2013). In Florida, shade-house structures

Table 1. Effect of colored shade nets on seasonal air temperature and relative humidity and midday leaf and root zone temperature (RZT) and photosynthetically active radiation $(P A R)$ in bell pepper, Tifton, GA, Spring 2015.

\begin{tabular}{lccccccccccc}
\hline & \multicolumn{2}{c}{ Seasonal air temp $\left({ }^{\circ} \mathrm{C}\right)$} & & \multicolumn{2}{c}{ Seasonal relative humidity $(\%)$} & & \\
Shade & Minimum & Mean & Maximum & & Minimum & Mean & Maximum & Midday RZT $\left({ }^{\circ} \mathrm{C}\right)$ & Midday leaf temp $\left({ }^{\circ} \mathrm{C}\right)$ & Midday $P A R\left(\mu \mathrm{mol} \cdot \mathrm{m}^{-2} \cdot \mathrm{s}^{-1}\right)$ \\
\hline Black & $22.32 \mathrm{a}^{\mathrm{z}}$ & $27.0 \mathrm{c}$ & $33.1 \mathrm{~b}$ & $49.5 \mathrm{a}$ & $69.9 \mathrm{a}$ & $87.0 \mathrm{~b}$ & $34.0 \mathrm{~b}$ & $985 \mathrm{~d}$ \\
Red & $22.28 \mathrm{ab}$ & $27.1 \mathrm{~b}$ & $33.1 \mathrm{~b}$ & & $46.8 \mathrm{c}$ & $65.9 \mathrm{~d}$ & $82.8 \mathrm{c}$ & $34.9 \mathrm{~b}$ & $31.8 \mathrm{~b}$ & $31.8 \mathrm{~b}$ & $1064 \mathrm{c}$ \\
Silver & $22.26 \mathrm{~b}$ & $27.1 \mathrm{~b}$ & $33.0 \mathrm{c}$ & $48.3 \mathrm{~b}$ & $68.8 \mathrm{~b}$ & $87.3 \mathrm{a}$ & $34.9 \mathrm{~b}$ & $31.9 \mathrm{~b}$ & $1102 \mathrm{bc}$ \\
White & $\mathrm{nd}^{\mathrm{y}}$ & nd & nd & nd & nd & nd & $35.2 \mathrm{~b}$ & $33.2 \mathrm{a}$ & $1135 \mathrm{~b}$ \\
Unshaded & $22.17 \mathrm{c}$ & $27.2 \mathrm{a}$ & $33.9 \mathrm{a}$ & $45.7 \mathrm{~d}$ & $67.6 \mathrm{c}$ & $86.9 \mathrm{~b}$ & $37.1 \mathrm{a}$ & $34.2 \mathrm{a}$ & $1851 \mathrm{a}$ \\
$P$ & $<0.0001$ & $<0.0001$ & $<0.0001$ & $<0.0001$ & $<0.0001$ & $<0.0001$ & $<0.0001$ & $<0.0001$ & $<0.0001$ \\
\hline
\end{tabular}

${ }^{\mathrm{z}}$ Means followed by the same letter are not significantly different based on Fisher's protected least significant difference test at $95 \%$ confidence.

${ }^{\mathrm{y}} \mathrm{nd}=$ not determined.

Table 2. Effect of colored shade nets on seasonal air temperature and relative humidity and midday leaf temperature and photosynthetically active radiation $(P A R)$ in bell pepper, Tifton, GA, Spring 2016.

\begin{tabular}{|c|c|c|c|c|c|c|c|c|}
\hline \multirow[b]{2}{*}{ Shade } & \multicolumn{3}{|c|}{ Seasonal air temp $\left({ }^{\circ} \mathrm{C}\right)$} & \multicolumn{3}{|c|}{ Seasonal relative humidity (\%) } & \multirow[b]{2}{*}{ Midday leaf temp $\left({ }^{\circ} \mathrm{C}\right)$} & \multirow[b]{2}{*}{ Midday $P A R\left(\mu \mathrm{mol} \cdot \mathrm{m}^{-2} \cdot \mathrm{s}^{-1}\right)$} \\
\hline & Minimum & Mean & Maximum & Minimum & Mean & Maximum & & \\
\hline Red & $20.49 \mathrm{c}$ & $26.3 \mathrm{~b}$ & $32.1 \mathrm{~b}$ & $39.7 \mathrm{c}$ & $58.4 \mathrm{c}$ & $79.0 \mathrm{~b}$ & $31.60 \mathrm{c}$ & $1204 \mathrm{~b}$ \\
\hline Unshaded & $20.66 \mathrm{a}$ & $26.6 \mathrm{a}$ & $32.6 \mathrm{a}$ & $41.3 \mathrm{~b}$ & $56.0 \mathrm{~d}$ & $71.5 \mathrm{c}$ & $33.77 \mathrm{a}$ & $1991 \mathrm{a}$ \\
\hline$P$ & $<0.0001$ & $<0.0001$ & $<0.0001$ & $<0.0001$ & $<0.0001$ & $<0.0001$ & 0.0002 & $<0.0001$ \\
\hline
\end{tabular}

${ }^{\mathrm{z}}$ Means followed by the same letter are not significantly different based on Fisher's protected least significant difference test at $95 \%$ confidence.

$\mathrm{y}_{\mathrm{nd}}=$ not determined

Table 3. Effect of colored shade nets on fruit yield and individual fruit weight in bell pepper, Tifton, GA, Spring 2015.

\begin{tabular}{|c|c|c|c|c|c|}
\hline \multirow[b]{2}{*}{ Shade } & \multicolumn{2}{|c|}{ Marketable } & \multicolumn{2}{|c|}{ Total } & \multirow[b]{2}{*}{ Fruit wt $(\mathrm{g}$} \\
\hline & $\left(1000 \cdot \mathrm{ha}^{-1}\right)$ & $\left(\mathrm{t} \cdot \mathrm{ha}^{-1}\right)$ & $\left(1000 \cdot \mathrm{ha}^{-1}\right)$ & $\left(\mathrm{t} \cdot \mathrm{ha}^{-1}\right)$ & \\
\hline Red & $476 \mathrm{a}$ & $54.2 \mathrm{a}$ & 510 & $56.8 \mathrm{a}$ & $113 \mathrm{a}$ \\
\hline Silver & $508 \mathrm{a}$ & $59.9 \mathrm{a}$ & 552 & $63.3 \mathrm{a}$ & $119 \mathrm{a}$ \\
\hline Unshaded & $164 \mathrm{~b}$ & $13.0 \mathrm{~b}$ & 179 & $13.8 \mathrm{~b}$ & $65 \mathrm{~b}$ \\
\hline$P$ & 0.049 & 0.0002 & 0.062 & 0.0003 & $<0.0001$ \\
\hline
\end{tabular}

${ }^{\mathrm{z}}$ Means within the same column followed by the same letter are not statistically different according to Fisher's protected least significant difference tes $(P \leq 0.05)$. 


\begin{tabular}{|c|c|c|c|c|c|}
\hline \multirow[b]{2}{*}{ Shade } & \multicolumn{2}{|c|}{ Marketable } & \multicolumn{2}{|c|}{ Total } & \multirow[b]{2}{*}{ Fruit wt $(\mathrm{g}$} \\
\hline & $\left(1000 \cdot \mathrm{ha}^{-1}\right)$ & $\left(\mathrm{t} \cdot \mathrm{ha}^{-1}\right)$ & $\left(1000 \cdot \mathrm{ha}^{-1}\right)$ & $\left(\mathrm{t} \cdot \mathrm{ha}^{-1}\right)$ & \\
\hline Red & $446 \mathrm{~b}$ & $47.5 \mathrm{bc}$ & $585 \mathrm{~b}$ & $56.4 \mathrm{~b}$ & $103 \mathrm{ab}$ \\
\hline Unshaded & $268 \mathrm{c}$ & $23.8 \mathrm{~d}$ & $309 \mathrm{c}$ & $26.2 \mathrm{c}$ & $90 \mathrm{c}$ \\
\hline$P$ & $<0.0001$ & $<0.0001$ & $<0.0001$ & $<0.0001$ & 0.0002 \\
\hline
\end{tabular}

${ }^{\mathrm{z}}$ Means within the same column followed by the same letter are not statistically different according to Fisher's protected least significant difference test $(P \leq 0.05)$.
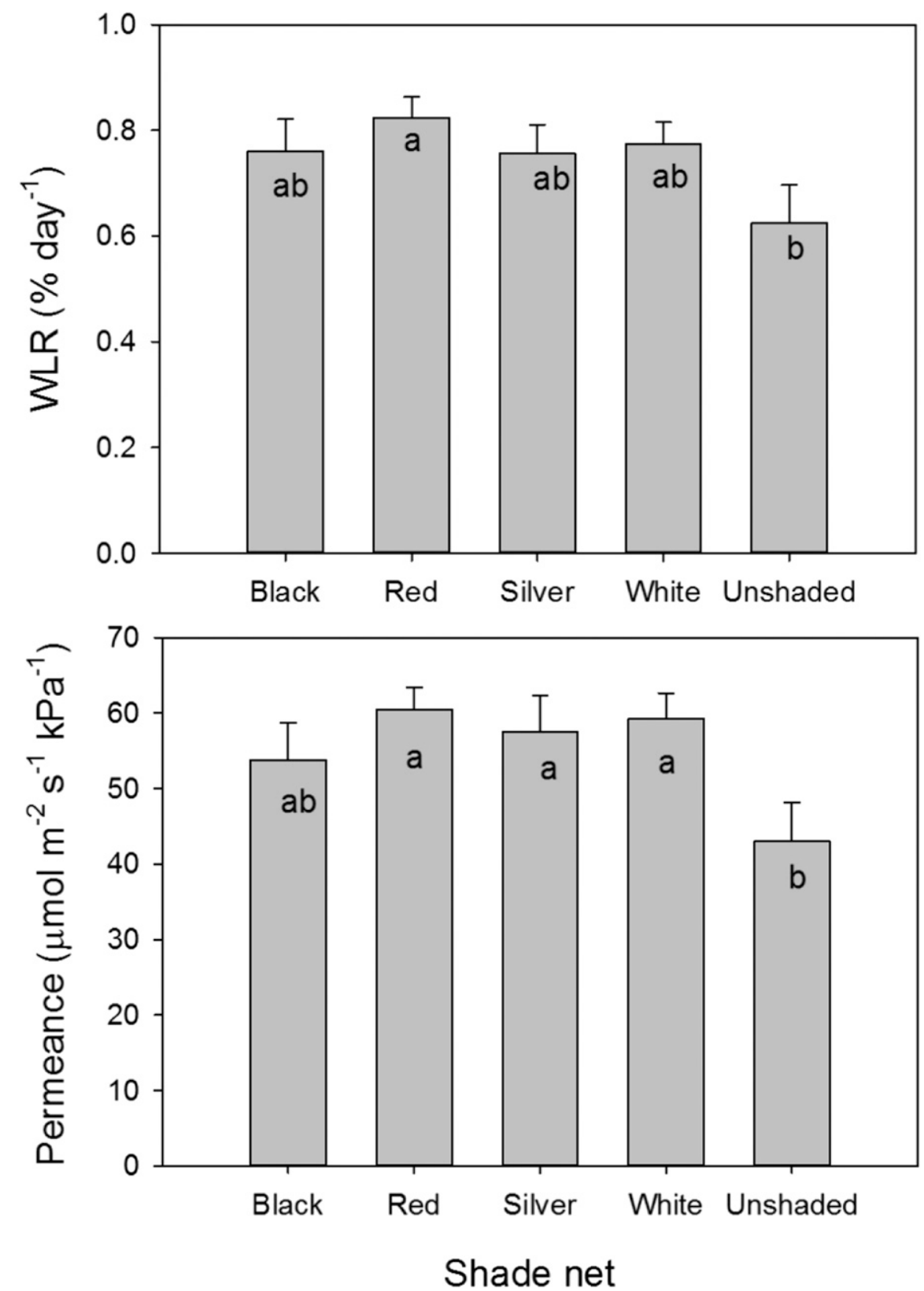

Fig. 2. Postharvest water loss and skin permeance of marketable bell pepper fruit grown under colored shade nets. Fruit kept at $20^{\circ} \mathrm{C}$ (vapor pressure difference of $1.50 \mathrm{kPa}$ ) for $7 \mathrm{~d}$, Tifton, GA.

with full covering had higher daily maximum air temperatures under red, blue, and pearl nets compared with black nets or in uncovered conditions. In the present study, colored shade nets (on structures with open sides) had little effect on air temperature, but reduced root zone temperatures compared with unshaded conditions; leaf temperatures were increased under white net and under unshaded conditions. Air temperatures were similar under the different colored shade nets probably because the sides of the structures were open, allowing for enhanced ventilation.

Fruit yield. Fruit marketable yields were reduced in the unshaded treatment and there were inconsistent differences in marketable yields among colored shade nets. Thus, light quality as modified by colored shade nets probably had a minor effect on fruit yields. In Israel, bell pepper plants under red, pearl, and yellow shade nets had increased fruit yields compared with plants under black net (Shahak et al., 2009). In other studies on colored shade nets in bell pepper, fruit yields were reduced in unshaded conditions (Ambrozy et al., 2016; Ayala-Tafoya et al., 2015). Decreased fruit yields in the unshaded treatment indicate that high temperature (and high VPD) conditions because of high irradiation were a major factor affecting the bell pepper crop.

Our finding that total and marketable fruit yields decreased with increasing leaf temperatures support the contention that high temperatures affect plant function under unshaded conditions. In fact, leaf net photosynthesis and stomatal conductance decreased with increasing midday leaf temperature above $32{ }^{\circ} \mathrm{C}$ (Díaz-Pérez and St. John, 2019). However, the mechanism through which fruit yields were reduced under unshaded conditions was probably not via a direct effect of high leaf temperature on leaf gas exchange because no relationships were observed between total fruit yield with either leaf net photosynthesis $\left(r^{2}=0.461 ; P<0.05\right)$ or stomatal conductance $\left(r^{2}=0.336 ; P<\right.$ $0.05)$. Instead, reduced plant water status resulting from increased evaporative demands under unshaded conditions may be a probable explanation for the reduced fruit yields. Reduced leaf net photosynthesis with increasing leaf temperature was probably caused by stomatal factors due to plant water stress rather than by nonstomatal factors, such as photo-inhibition; this suggestion is supported by the similar PSII efficiency values obtained in unshaded conditions and those under shade nets (Díaz-Pérez and St. John, 2019).

In addition, leaf temperature was not related with $P A R$ under the shade nets, suggesting that the differences in leaf temperature were not primarily due to differences in PAR. Instead, differences in the amount of IR light traversing the shade nets probably resulted in the observed differences in leaf temperature. In 2015, leaf temperature ranged from $31.8{ }^{\circ} \mathrm{C}$ under black net and $34.2{ }^{\circ} \mathrm{C}$ under 

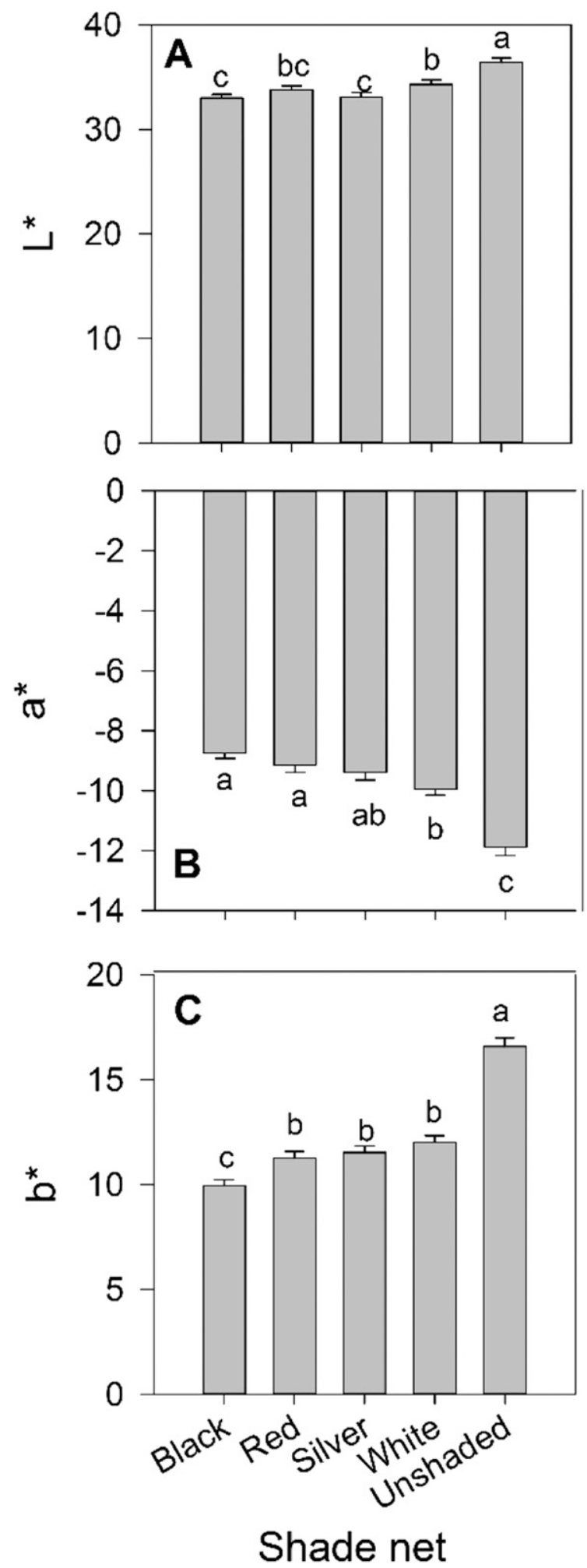

Fig. 3. Skin color of marketable bell pepper fruit grown under different colored shade nets, Tifton, GA Color $\mathrm{L}^{*}$ value goes from 0 (white) to 100 (black); $\mathrm{a}^{*}$ value from - $\mathrm{a}$ (green) to $+\mathrm{a}$ (red); $\mathrm{b}^{*}$ value from $-\mathrm{b}$ (blue) to $+\mathrm{b}$ (yellow).

unshaded conditions, with their respective marketable yields being 61 and $13 \mathrm{t} \cdot \mathrm{ha}^{-1}$. Increased leaf temperature may result in decreased rates of leaf net photosynthesis and consequently decreased fruit yields under warm conditions. Thus, shade nets played an important role in ameliorating heat stress and water stress by reducing solar radiation, and as a result reducing leaf temperature and leaf transpiration through a decrease in evaporative demand between leaves and the surrounding air.

Postharvest fruit transpiration. Bell pepper fruit grown under unshaded conditions (i.e., full solar radiation) had reduced fruit water loss rates and reduced skin permeance compared with fruit produced under colored shade nets. Interestingly, shade net color did not affect either the rate of fruit water loss or fruit skin permeance. The rate of postharvest fruit water loss or transpiration strongly affects fruit quality and shelf life (Ben-Yehoshua and Weichmann, 1987; Díaz-Pérez, 2019). In bell pepper, fruit transpiration is restricted due to lack of stomata and a relatively thick cuticle (Parsons et al., 2013). Approximately $26 \%$ of fruit water loss in bell pepper occurs via the calyx (Díaz-Pérez et al., 2007).

The effects of shade nets on the rate of fruit water loss in bell pepper may be variable. In Georgia, the rate of fruit water loss in bell pepper was unaffected by shade level in black nets, although there were differences between cultivars (Díaz-Pérez, 2014). In Israel, bell pepper fruit under pearl shade net had a reduced water loss rate and increased firmness compared with fruit under a black net (Kong et al., 2013). In the present study, the fact that fruit skin permeance was unaffected by colored net color indicates that the transpirational properties of the fruit epidermis were not influenced by the colored nets. These results suggest that light quantity rather than light quality (as modified by colored shade nets) influenced the rate of fruit water loss in bell pepper. Fruit response to light may be similar to that shown by leaves in which sun leaves have reduced cuticular transpiration compared with shade leaves (Larcher, 1995). Thus, increased bell pepper fruit transpiration under colored shade nets was probably due to differences in cuticle amount, composition, or morphology resulting from light and temperature effects (Hull et al., 1975; Kerstiens, 1996). Cuticle thickness or composition, however, were not measured in the present study. In a cross between Capsicum annuum and Capsicum chinense, fruit water loss was more related with cuticle composition than with cuticle thickness (Parsons et al., 2012).

In 'Keystone', 'NuMex R Naky', and 'Santa Fe Grande' peppers differing in physical characteristics, rate of fruit water loss was positively correlated with initial water content, surface area-to-volume ratio, and cuticle thickness (Lownds et al., 1993). In bell pepper, the rate of fruit water loss was found to decrease as fruit water content declines under storage conditions (DíazPérez et al., 2007). In the present study, fruit water content was probably reduced in unshaded conditions because of the high evaporative demand conditions. This reduced fruit water content may explain at least partially the diminished rate of transpiration of such fruit.

Fruit skin color and composition. Shade net treatments showed different fruit skin color values; the unshaded treatment had the smallest (more negative) $a^{*}$ value and the highest $b^{*}$ value. Environmental conditions as modified by shade nets may affect fruit phytochemical content (Ilic and Fallik, 
Table 5. Effect of colored shade nets on chemical composition of marketable bell pepper fruit, Tifton, GA, Spring 2015.

\begin{tabular}{|c|c|c|c|c|c|}
\hline Shade net & $\mathrm{SSC}^{\mathrm{z}}(\%)$ & Total phenols [gallic acid equivalent $\left(\mathrm{mg} \cdot \mathrm{L}^{-1}\right)$ ] & Flavonoids [quercetin equivalent $\left(\mathrm{mg} \cdot \mathrm{mL}^{-1}\right)$ ] & CUPRAC $^{y}(\mu \mathrm{M})$ & $\operatorname{TEAC}^{\mathrm{x}}(\mu \mathrm{M})$ \\
\hline Silver & $3.6 \mathrm{bc}$ & $526 \mathrm{c}$ & $35.5 \mathrm{c}$ & $2062 \mathrm{~b}$ & $3731 \mathrm{~b}$ \\
\hline White & $3.9 \mathrm{ab}$ & $582 \mathrm{ab}$ & $42.9 \mathrm{ab}$ & $2507 \mathrm{a}$ & $4571 \mathrm{a}$ \\
\hline$P$ & 0.004 & $<0.0001$ & 0.001 & $<0.0001$ & $<0.0001$ \\
\hline
\end{tabular}

${ }^{\mathrm{z}} \mathrm{SSC}=$ soluble solids content.

${ }^{\mathrm{y}}$ CUPRAC $=$ Cupric Reducing Antioxidant Capacity.

${ }^{\mathrm{x}} \mathrm{TEAC}=$ Trolox Equivalent Antioxidant Capacity.

${ }^{\mathrm{w}}$ Means within the same column followed by the same letter are not statistically different according to Fisher's protected least significant difference test $(P \leq 0.05)$.

Table 6. Effect of colored shade nets on chemical composition of marketable bell pepper fruit, Tifton, GA, Spring 2016.

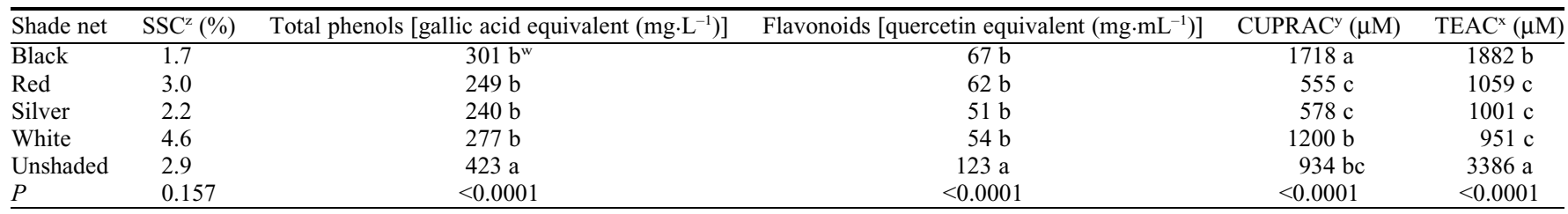

${ }^{\mathrm{z}} \mathrm{SSC}=$ soluble solids content.

${ }^{\mathrm{y}}$ CUPRAC $=$ Cupric Reducing Antioxidant Capacity.

${ }^{\mathrm{x}} \mathrm{TEAC}=$ Trolox Equivalent Antioxidant Capacity.

${ }^{\text {w } M e a n s}$ within the same column followed by the same letter are not statistically different according to Fisher's protected least significant difference test $(P \leq 0.05)$.

2017). Fruit color values may be predictors of fruit pigment concentrations. In pumpkin and squash, the color a* value was found to be positively correlated with total carotenoids (Itle and Kabelka, 2009). In tomato, the color $a^{*}$ value and the ratio $\left(a^{*} / b^{*}\right)^{2}$ were positively correlated with lycopene concentration (Dsouza et al., 1992). In our study, the reduced $a^{*}$ value in bell pepper fruit under unshaded conditions probably indicates a diminished fruit carotenoid concentration. In Serbia, bell pepper fruit was found to have decreased carotenoid concentration when grown in unshaded conditions compared with fruit under red, black, pearl, and blue nets (Ilic et al., 2017). Tomato fruit in unshaded conditions and under white shade net showed reduced lycopene content compared with fruit under black, blue, or red shade nets; reduced lycopene concentration was attributed to high air temperatures under the nets (Helyes et al., 2007; Ilic et al., 2015).

Bell pepper fruit SSC responded inconsistently to shade treatments in the two seasons and fruit under black shade net had reduced SSC in 1 of the 2 years. Low fruit SSC values under black shade may be attributed to either reduced leaf net photosynthesis or increased fruit respiration due to high temperatures, resulting in reduced sugar accumulation in the fruit. Fruit SSC, however, was not related with leaf temperature $(r=$ 0.087; $P>0.05)$. In Georgia, SSC in bell pepper fruit under black shade net decreased with increasing shade level (Díaz-Pérez, 2014). In Serbia, bell pepper under red, black, pearl, or blue nets produced fruit with reduced SSC compared with fruit in open field (Ilic et al., 2017).

Fruit total phenols, flavonoids, and antioxidant capacity (TEAC) were among the highest in unshaded conditions, although there were inconsistent responses among colored shade nets in the 2 years. In baby spinach, flavonoids were more abundant under intense solar radiation and decreased under colored shade nets (Bergquist et al., 2007). Bell pepper fruit under pearl shade net had reduced ascorbic acid content and antioxidant activity compared with fruit under black shade net (Kong et al., 2013). The effect of colored shade nets on compounds of secondary metabolism, such as phenols and flavonoids and antioxidant capacity requires further studies due to the importance of these compounds on human diet and health.

In conclusion, the present study is consistent with previous reports indicating that shade nets increase fruit yield and quality in bell pepper compared with unshaded conditions. Colored shade nets have been reported to modify the light microenvironment of the crop, influencing the action of plant photoreceptors and as a consequence altering plant morphology and physiology (Stamps, 2009). The present study, however, showed no consistent significant differences in fruit total and marketable yields, postharvest fruit transpiration, and fruit chemical composition under colored shade nets. Reduced leaf temperatures under the shade nets, regardless of net color, played a major role in improving bell pepper fruit yield and quality by presumably reducing plant water stress due to decreased evaporative demand compared with unshaded conditions.

\section{Literature Cited}

Ambrozy, Z., H. Daood, Z. Nagy, H.D. Ledo, and L. Helyes. 2016. Effect of net shading technology and harvest times on yield and fruit quality of sweet pepper. Appl. Ecol. Environ. Res. 14:99-109.
Arthurs, S.P., R.H. Stamps, and F.F. Giglia. 2013. Environmental modification inside photoselective shadehouses. HortScience 48:975-979.

Ayala-Tafoya, F., R. Sánchez-Madrid, L. PartidaRuvalcaba, M.G. Yáñez-Juárez, F.H. RuizEspinosa, T.D.V. Alcaraz, M. Valenzuela-López, and J.M. Parra-Delgado. 2015. Bell pepper production under colored shade nets. Rev. Fitotec. Mex. 38:93-99.

Barros, L., P. Baptista, and I.C.F.R. Ferreira. 2007. Effect of Lactarius piperatus fruiting body maturity stage on antioxidant activity measured by several biochemical assays. Food Chem. Toxicol. 45:1731-1737.

Ben-Yehoshua, S. and J. Weichmann. 1987. Transpiration, water stress, and gas exchange, $\mathrm{p}$. 113-170. In: J. Weichmann (ed.). Postharvest physiology of vegetables. Marcel Dekker, New York, NY.

Bergquist, S.Å., U.E. Gertsson, L.Y.G. Nordmark, and M.E. Olsson. 2007. Effects of shade nettings, sowing time and storage on baby spinach flavonoids. J. Sci. Food Agr. 87:2464-2471.

Castro-Concha, L.A., J. Tuyub-Che, A. MooMukul, F.A. Vazquez-Flota, and M.L. MirandaHam. 2014. Antioxidant capacity and total phenolic content in fruit tissues from accessions of Capsicum chinense Jacq. (Habanero pepper) at different stages of ripening. Sci. World J. 2014: 809073.

Cerny, T.A., J.E. Faust, D.R. Layne, and N.C Rajapakse. 2003. Influence of photoselective films and growing season on stem growth and flowering of six plant species. J. Amer. Soc. Hort. Sci. 128:486-491.

Díaz-Pérez, J.C. 2010. Bell Pepper (Capsicum annuum L.) grown on plastic film mulches: Effects on crop microenvironment, physiological attributes, and fruit yield. HortScience 45:1196-1204.

Díaz-Pérez, J.C. 2014. Bell pepper (Capsicum annuum L.) crop as affected by shade level: Fruit yield, quality, postharvest attributes, and incidence of Phytophthora blight (caused by Phytophthora capsici Leon.). HortScience 49:891-900. 
Díaz-Pérez, J.C. 2019. Chapter 8 - Transpiration, p. 157-173. In: E.M. Yahia (ed.). Postharvest physiology and biochemistry of fruits and vegetables. Woodhead Publishing, Duxford, UK.

Díaz-Pérez, J.C., M.D. Muy-Rangel, and A.G. Mascorro. 2007. Fruit size and stage of ripeness affect postharvest water loss in bell pepper fruit (Capsicum anпиит L.). J. Sci. Food Agr. 87:68-73.

Díaz-Pérez, J.C. and K. St. John. 2019. Bell pepper (Capsicum annuиm L.) under colored shade nets: Plant growth and physiological responses. HortScience 54:1795-1801.

Dsouza, M.C., S. Singha, and M. Ingle. 1992. Lycopene concentration of tomato fruit can be estimated from chromaticity values. HortScience 27:465-466.

Helyes, L., A. Lugasi, and Z. Pek. 2007. Effect of natural light on surface temperature and lycopene content of vine ripened tomato fruit. Can. J. Plant Sci. 87:927-929.

Hull, H.M., H.L. Morton, and J.R. Wharrie. 1975. Environmental influences on cuticle development and resultant foliar penetration. Bot. Rev. 41:421-451.

Ilic, Z., L. Milenzovic, M. Duriovka, and N. Kapoulas. 2011. The effect of color shade nets on the greenhouse climate and pepper yield. 46th Croation and 6th International Symposium on Agriculture, Opatija, Croatia, 14-18 February 2011, Proceedings, p. 529-532.

Ilic, Z.S. and E. Fallik. 2017. Light quality manipulation improves vegetable quality at harvest and postharvest: A review. Environ. Exp. Bot. 139:79-90.

Ilic, Z.S., L. Milenkovic, L. Sunic, S. Barac, J. Mastilovic, Z. Kevresan, and E. Fallik. 2017. Effect of shading by coloured nets on yield and fruit quality of sweet pepper. ZemdirbysteAgriculture 104:53-62.
Ilic, Z.S., L. Milenkovic, L. Sunic, and E. Fallik. 2015. Effect of coloured shade-nets on plant leaf parameters and tomato fruit quality. J. Sci. Food Agr. 95:2660-2667.

Itle, R.A. and E.A. Kabelka. 2009. Correlation between $\mathrm{L}^{*} \mathrm{a}^{*} \mathrm{~b} *$ color space values and carotenoid content in pumpkins and squash (Cucurbita spp.). HortScience 44:633-637.

Kerstiens, G. 1996. Cuticular water permeability and its physiological significance. J. Expt. Bot. 47:1813-1832.

Kong, Y., L. Avraham, Y. Perzelan, S. AlkalaiTuvia, K. Ratner, Y. Shahak, and E. Fallik. 2013. Pearl netting affects postharvest fruit quality in 'Vergasa' sweet pepper via light environment manipulation. Scientia Hort. 150: 290-298.

Larcher, W. 1995. Physiological plant ecology. Ecophysiological and stress physiology of functional groups. Springer, Berlin.

Lownds, N.K., M. Banaras, and P.W. Bosland. 1993. Relationships between postharvest water-loss and physical-properties of pepper fruit (Capsicum annuum L.). HortScience 28: $1182-1184$.

McGuire, R.G. 1992. Reporting of objective color measurements. HortScience 27:1254-1255.

Ombódi, A., Z. Péc, P. Szuvandzsiev, Z. Tóthné Taskovics, A. Kóházi-Kis, A. Kovács, H. Ledóné Darázsi, and L. Helyes. 2015. Effects of external coloured shade nets on sweet peppers cultivated in walk-in plastic tunnels. Not. Bot. Horti Agrobot. Cluj-Napoca 43:398-403.

Parsons, E.P., S. Popopvsky, G.T. Lohrey, S. Alkalai-Tuvia, Y. Perzelan, P. Bosland, P.J. Bebeli, I. Paran, E. Fallik, and M.A. Jenks. 2013. Fruit cuticle lipid composition and water loss in a diverse collection of pepper (Capsicum). Physiol. Plant. 149:160-174.
Parsons, E.P., S. Popopvsky, G.T. Lohrey, S.Y. Lu, S. Alkalai-Tuvia, Y. Perzelan, I. Paran, E. Fallik, and M.A. Jenks. 2012. Fruit cuticle lipid composition and fruit post-harvest water loss in an advanced backcross generation of pepper (Capsicum sp.). Physiol. Plant. 146:15-25.

Rawat, S., I.D. Bhatt, R.S. Rawal, and S.K. Nandi. 2014. Effect of developmental stage on total phenolics composition and anti-oxidant activities in Hedychium spicatum Buch.-Ham. ex. D. Don. J. Hort. Sci. Biotechnol. 89:557-563.

Rylski, I. 1986. Improvement of pepper fruit quality and timiing of harvest by shader under high solar radiation conditions. Acta Hort. 191:211228.

Shahak, Y. 2008. Photo-selective netting for improved performance of horticultural crops. A review of ornamental and vegetable studies carried out in Israel. Acta Hort. 770:161-168.

Shahak, Y., D. Ben-Yakir, Y. Offir, H. Yehezkel, A. Goren, and E. Fallik. 2009. Photoselective shade netting for improving vegetable productivity, pre- and postharvest quality and pest control. HortScience 44:1077.

Singleton, V.L., R. Orthofer, and R.M. LamuelaRaventos. 1999. Analysis of total phenols and other oxidation substrates and antioxidants by means of Folin-Ciocalteu reagent. Methods Enzymol. 299:152-178.

Stamps, R.H. 2009. Use of colored shade netting in horticulture. HortScience 44:239-241.

USDA. 2005. United States standards for grades of sweet bell pepper. United States Department of Agriculture, Washington, D.C.

Wien, H.C. 1997. Peppers, p. 259-293. In: H.C. Wien (ed.). The physiology of vegetable crops. CAB International, Ithaca, NY. 